\title{
Intercept of minute ventilation versus carbon dioxide output relationship as an index of ventilatory inefficiency in chronic obstructive pulmonary disease
}

\author{
Fang $\operatorname{Lin}^{1} \wedge$, Shan Nie ${ }^{1}$, Ranran $\mathrm{Zhao}^{1}, \mathrm{Min} \mathrm{Cao}^{2}$, Wei Yuan ${ }^{1}$, Yunxiao $\mathrm{Li}^{1}$, Chunting $\operatorname{Tan}^{1}$, Bo Xu ${ }^{1}$, \\ Haoyan Wang ${ }^{1}$
}

${ }^{1}$ Department of Respiratory Medicine, Capital Medical University Affiliated Beijing Friendship Hospital, Beijing, China; ${ }^{2}$ Department of CardioPulmonary Function, Capital Medical University Affiliated Beijing Chest Hospital, Beijing Tuberculosis and Thoracic Tumor Research Institute, Beijing, China

Contributions: (I) Conception and design: H Wang, B Xu; (II) Administrative support: H Wang; (III) Provision of study materials or patients: H Wang, F Lin, S Nie, R Zhao; (IV) Collection and assembly of data: F Lin, S Nie, R Zhao, W Yuan, Y Li, C Tan; (V) Data analysis and interpretation: F Lin; (VI) Manuscript writing: All authors; (VII) Final approval of manuscript: All authors.

Correspondence to: Haoyan Wang, MD; Bo Xu, MD. Department of Respiratory Medicine, Capital Medical University Affiliated Beijing Friendship Hospital, No. 95 Yong An Road, Xicheng District, Beijing 100050, China. Email: haoyanw@ccmu.edu.cn; xubo_ally@126.com.

Background: Ventilatory inefficiency contributes to exercise intolerance in chronic obstructive pulmonary disease (COPD). The intercept of the minute ventilation $\left(\dot{\mathrm{V}}_{\mathrm{E}}\right) v s$. carbon dioxide output $\left(\dot{\mathrm{VCO}}_{2}\right)$ plot is a key ventilatory inefficiency parameter. However, its relationships with lung hyperinflation (LH) and airflow limitation are not known. This study aimed to evaluate correlations between the $\dot{\mathrm{V}}_{\mathrm{E}} / \dot{\mathrm{V} C O}_{2}$ intercept and LH and airflow limitation to determine its physiological interpretation as an index of functional impairment in COPD.

Methods: We conducted a retrospective analysis of data from 53 COPD patients and 14 healthy controls who performed incremental cardiopulmonary exercise tests (CPETs) and resting pulmonary function assessment. Ventilatory inefficiency was represented by parameters reflecting the $\dot{\mathrm{V}}_{\mathrm{E}} / \dot{\mathrm{VCO}}_{2}$ nadir and slope (linear region) and the intercept of $\dot{\mathrm{V}}_{\mathrm{E}} / \dot{\mathrm{VCO}}_{2}$ plot. Their correlations with measures of $\mathrm{LH}$ and airflow limitation were evaluated.

Results: Compared to control, the slope $(30.58 \pm 3.62, \mathrm{P}<0.001)$ and intercept $(4.85 \pm 1.11 \mathrm{~L} / \mathrm{min}, \mathrm{P}<0.05)$ were higher in $\mathrm{COPD}_{\text {stages1-2 }}$, leading to a higher nadir $(31.47 \pm 4.47, \mathrm{P}<0.01)$. Despite an even higher intercept in $\mathrm{COPD}_{\text {stages } 3-4}(7.16 \pm 1.41, \mathrm{P}<0.001)$, the slope diminished with disease progression (from $30.58 \pm 3.62$ in $\mathrm{COPD}_{\text {stages } 1-2}$ to $26.84 \pm 4.96$ in $\left.\mathrm{COPD}_{\text {stages } 3-4}, \mathrm{P}<0.01\right)$. There was no difference in nadir among COPD groups and higher intercepts across all stages. The intercept was correlated with peak $\dot{V}_{\mathrm{E}}$ /maximal voluntary ventilation $(\mathrm{MVV})(\mathrm{r}=0.489, \mathrm{P}<0.001)$ and peak $\dot{\mathrm{VO}}_{2} /$ Watt $(\mathrm{r}=0.354, \mathrm{P}=0.003)$. The intercept was positively correlated with residual volume $(\mathrm{RV}) \%$ predicted $(\mathrm{r}=0.571, \mathrm{P}<0.001), \mathrm{RV} /$ total lung capacity (TLC) $(\mathrm{r}=0.588$, $\mathrm{P}<0.001)$, peak tidal volume $\left(\mathrm{V}_{\mathrm{T}}\right) / \mathrm{FEV}_{1}(\mathrm{r}=0.482, \mathrm{P}<0.001)$ and negatively correlated with rest inspiratory capacity (IC)/TLC $(\mathrm{r}=-0.574, \mathrm{P}<0.001)$, peak $\mathrm{V}_{\mathrm{T}} / \mathrm{TLC}(\mathrm{r}=-0.585, \mathrm{P}<0.001)$, airflow limitation forced expiratory volume in $1 \mathrm{~s}\left(\mathrm{FEV}_{1}\right) \%$ predicted $(\mathrm{r}=-0.606, \mathrm{P}<0.001)$, and $\mathrm{FEV}_{1} /$ forced vital capacity $(\mathrm{FVC})$ $(\mathrm{r}=-0.629, \mathrm{P}<0.001)$.

Conclusions: $\dot{\mathrm{V}}_{\mathrm{E}} / \dot{\mathrm{VCO}}_{2}$ intercept was consistently correlated with worsening static and dynamic LH, pulmonary gas exchange, and airflow limitation in COPD. The $\dot{\mathrm{V}}_{\mathrm{E}} / \dot{\mathrm{VCO}}_{2}$ intercept emerged as a useful index of ventilatory inefficiency in COPD patients.

Keywords: Chronic obstructive pulmonary disease (COPD); ventilatory inefficiency; exercise; lung hyperinflation $(\mathrm{LH})$; airflow limitation

^ ORCID: 0000-0002-1009-9871. 
Submitted Aug 23, 2020. Accepted for publication Jan 13, 2021.

doi: $10.21037 /$ jtd-20-2725

View this article at: http://dx.doi.org/10.21037/jtd-20-2725

\section{Introduction}

Activity-related dyspnea is the defining complaint in patients with chronic obstructive pulmonary disease (COPD) (1). The limitations in activity and dyspnea are multifactorial. The development of lung hyperinflation (LH) plays an important role in the pathophysiologies of dyspnea and exercise intolerance (2). LH has a static and dynamic component. Static lung hyperinflation (sLH) is defined as functional residual capacity (FRC) equal to increased relaxation respiratory volume $(\mathrm{V} r)$ resulting from loss of lung elastic recoil, while dynamic lung hyperinflation (dLH) when FRC exceeds $\mathrm{Vr}$ (3). dLH that occurs when the expiratory time becomes insufficient to allow the lung to achieve full exhalation yields an increased end-expiratory lung volume (EELV) during exercise (4). LH increases ventilatory workload and decreases inspiratory muscle pressure-generating capacity, despite some compensatory mechanisms (5). The diminished ventilatory capacity coupled with the increased ventilatory demand during exercise results in exercise intolerance.

The minute ventilation $\left(\dot{\mathrm{V}}_{\mathrm{E}}\right)$ vs. carbon dioxide production $\left(\dot{\mathrm{V}} \mathrm{CO}_{2}\right)$ relationship is a measure of the ventilatory efficiency at removing $\mathrm{CO}_{2}$ produced by the body. Early in exercise, $\dot{\mathrm{V}}_{\mathrm{E}} / \dot{\mathrm{V} C \mathrm{CO}_{2}}$ decreases due to a lower in dead space ventilation $\left(\mathrm{V}_{\mathrm{D}}\right)$ /tidal volume $\left(\mathrm{V}_{\mathrm{T}}\right)$ ratio. When the lactic acidosis first develops, both $\dot{\mathrm{V}}_{\mathrm{E}}$ and $\dot{\mathrm{V}} \mathrm{CO}_{2}$ increase curvilinearly, resulting in no further change in $\dot{\mathrm{V}}_{\mathrm{E}} / \dot{\mathrm{VCO}}_{2}$ and $\mathrm{P}_{\mathrm{ET}} \mathrm{CO}_{2}$. (isocapnic buffering). The $\dot{\mathrm{V}}_{\mathrm{E}} / \dot{\mathrm{V} C O}$ nadir is typically reached at isocapnic buffering period and then ventilation starts to increase to compensate for lactic acidosis at the respiratory compensation point (RCP) (6). The $\dot{\mathrm{V}}_{\mathrm{E}} / \dot{\mathrm{VCO}}_{2}$ nadir was found to be highly reproducible in healthy subjects (7) and COPD patients (8). However, the $\dot{\mathrm{V}}_{\mathrm{E}} / \dot{\mathrm{VCO}}_{2}$ nadir might underestimate ventilatory inefficiency if the descending curve is prematurely interrupted by lactic acidosis or a very short test duration (9). On the other hand, the $\dot{\mathrm{V}}_{\mathrm{E}} / \dot{\mathrm{V} C O}$ ratio might be higher than the nadir due to the hyperventilation response to late-exercise acidosis in patients who can exercise beyond the RCP (10).

The $\dot{\mathrm{V}}_{\mathrm{E}} / \dot{\mathrm{V}} \mathrm{CO}_{2}$ slope has been used to assess disease progression and identify the presence of comorbidities
(11-16). However, in many patients with moderate-tosevere COPD, the partial pressure of carbon dioxide $\left(\mathrm{PaCO}_{2}\right)$ and mechanical constraints will predictably flatten the $\dot{\mathrm{V}}_{\mathrm{E}} / \dot{\mathrm{V} C O}$ curve. In these patients, the $\dot{\mathrm{V}}_{\mathrm{E}} / \dot{\mathrm{V}} \mathrm{CO}_{2}$ slope might paradoxically decrease as the disease progresses if $\mathrm{CO}_{2}$ retention worsens during exercise. It is plausible that the $\dot{\mathrm{V}}_{\mathrm{E}} / \dot{\mathrm{V}} \mathrm{CO}_{2}$ nadir might be stable while the slope and intercept change in opposite directions despite COPD progression (10).

The $\dot{\mathrm{V}}_{\mathrm{E}} / \dot{\mathrm{V} C O} \mathrm{CO}_{2}$ intercept is a novel parameter derived from $\dot{\mathrm{V}}_{\mathrm{E}} v s$. $\dot{\mathrm{V}}_{2}$ relationship by extrapolating a regression line during exercise, which theoretically equates to the $V_{D}(17)$ and cannot be constrained by dynamic mechanics (unlike the slope) or the test duration (unlike the nadir) $(10,18)$. Indeed, $\dot{\mathrm{V}}_{\mathrm{E}} / \dot{\mathrm{V}} \mathrm{CO}_{2}=863 /\left[\mathrm{PaCO}_{2} \times\left(1-\mathrm{V}_{\mathrm{D}} / \mathrm{V}_{\mathrm{T}}\right)\right]$. If two periods- $-\mathrm{PaCO}_{2}$ and the $\mathrm{V}_{\mathrm{D}} / \mathrm{V}_{\mathrm{T}}$ ratio are constant during exercise, no intercept can appear. Otherwise, we can show an intercept during exercise because $\mathrm{PaCO}_{2}$ increases with greater exercise intensity, even in the absence of $\mathrm{V}_{\mathrm{D}}$.

The $\dot{\mathrm{V}}_{\mathrm{E}} / \dot{\mathrm{V}}_{\mathrm{CO}}$ intercept depends on the patterns of change in multiple parameters during exercise. The increased intercept in COPD patients might result from an altered breathing strategy such as increased breathing frequency to compensate for reduced $V_{T}$ secondary to greater mechanical constraints, and/or a progressive ventilation-perfusion mismatch in COPD patients (1). Thus, the $\dot{\mathrm{V}}_{\mathrm{E}} / \dot{\mathrm{V} C O}_{2}$ intercept increases with greater disease severity in COPD patients, and it seems to be a particularly useful index for ventilatory inefficiency across the COPD severity continuum (10). However, the clinical implications of the $\dot{\mathrm{V}}_{\mathrm{E}} / \dot{\mathrm{VCO}}_{2}$ intercept and its association with $\mathrm{LH}$ in COPD have not been formally examined except few study reported the relationship between intercept and dLH (19).

This study aimed to evaluate the relationship between the $\dot{\mathrm{V}}_{\mathrm{E}} / \dot{\mathrm{V}} \mathrm{CO}_{2}$ intercept and $\mathrm{LH}$ and airflow limitation in patients with COPD. We hypothesized that the $\dot{\mathrm{V}}_{\mathrm{E}} / \dot{\mathrm{V}} \mathrm{CO}_{2}$ intercept correlated well with measures of both $\mathrm{LH}$ and airflow limitation and could be a particularly useful index for ventilatory inefficiency in COPD.

We present the following article in accordance with the STROBE reporting checklist (available at http://dx.doi. org/10.21037/jtd-20-2725). 


\section{Methods}

\section{Study participants}

This study was a retrospective analysis of incremental cardiopulmonary exercises data collected from Jan. 1, 2016 to Dec. 31, 2019 at the Respiratory Investigation Unit, Beijing Friendship Hospital, Capital Medical University (Beijing, China). The study was conducted in accordance with the Declaration of Helsinki (as revised in 2013). Participants were males and females aged $\geq 40$ years with body mass index (BMI) of $18-35 \mathrm{~kg} / \mathrm{m}^{2}$ and given informed consent before taking part in. The study was approved by the Institutional ethics committee of Beijing Friendship Hospital of Capital Medical University (No. 2018-P2048-01) and the written informed consent was obtained from every participant. The 53 patients were current or ex-smokers (smoking history $\geq 10$ pack-years) and had a well-established diagnosis of COPD (20) without asthma or other pulmonary diseases. Patients were required to have had no exacerbation in the preceding 6 weeks. Fourteen control subjects with no smoking history were in the same age range and they had no major orthopedic, neuromuscular, cardiac or metabolic diseases, to allow them to safely undertake the incremental exercise tests.

\section{Pulmonary function tests}

Each subject underwent resting spirometry (MasterScreen Body, CareFusion, Hoechberg, Germany), including inspiratory capacity (IC) assessment. Body plethysmography was performed to measure residual volume (RV), TLC and diffusing capacity of the lungs for carbon monoxide $\left(\mathrm{DL}_{\mathrm{CO}}\right)$. Patients took $400 \mu \mathrm{g}$ albuterol by inhalation $20 \mathrm{~min}$ before testing. All pulmonary function tests fulfilled the American Thoracic Society/European Respiratory Society guidelines (21).

\section{Cardiopulmonary exercise test (CPET)}

Symptom-limited incremental exercise testing was performed on an electronically braked cycle ergometer (ViaSprint, CareFusion, Hoechberg, Germany) with a pedaling rate of $60 / \mathrm{min}$. After $3 \mathrm{~min}$ of rest and $3 \mathrm{~min}$ of unloaded pedaling, the work rate (WR) was increased by $5-15 \mathrm{~W} / \mathrm{min}$ in a ramp fashion $\left(5 \mathrm{~W} / \mathrm{min}\right.$ if $\mathrm{FEV}_{1}<1.0 \mathrm{~L}$ and $10 \mathrm{~W} / \mathrm{min}$ if $\mathrm{FEV}_{1} \geq 1.0 \mathrm{~L}$ for the COPD patients; $15 \mathrm{~W} / \mathrm{min}$ for the control subjects, with repetition at $20 \mathrm{~W} / \mathrm{min}$ if the peak WR was $\geq 200 \mathrm{~W}$ ). Participants were asked to continue to exercise to the limit of tolerance, marked by the inability (despite encouragement) to maintain pedaling frequency or intolerable shortness of breath. Any participant with chest pain suggestive of ischemia, ventricular tachycardia and blood pressure (BP) $\geq 240 / 130 \mathrm{mmHg}$ was prevented further exercise. Participants were continuously monitored with a 12-lead electrocardiogram and blood pressure by sphygmomanometer every $2 \mathrm{~min}$.

\section{Data collection}

Respiratory gas exchange $\left(\dot{\mathrm{V}}_{\mathrm{E}}, \dot{\mathrm{V}} \mathrm{O}_{2}\right.$, and $\left.\dot{\mathrm{V}} \mathrm{CO}_{2}\right)$ and $\mathrm{V}_{\mathrm{T}}$ were measured breath-by-breath throughout the exercise testing. Serial measurements of these parameters were averaged at consecutive $30 \mathrm{~s}$ data. Arterial oxygen saturation was measured noninvasively by pulse oximetry $\left(\mathrm{SpO}_{2} \%\right)$. The $\dot{\mathrm{V}}_{\mathrm{E}} / \dot{\mathrm{V} C O}{ }_{2}$ nadir and peak $\dot{\mathrm{V}}_{\mathrm{E}} / \dot{\mathrm{V} C \mathrm{CO}_{2}}$ were averaging the consecutive $30 \mathrm{~s}$ data points at lowest and peak time, respectively (7). The slope of the $\dot{\mathrm{V}}_{\mathrm{E}} / \dot{\mathrm{V}} \mathrm{CO}_{2}$ relationship was determined based on the $\dot{\mathrm{V}}_{\mathrm{E}} v s \cdot \dot{\mathrm{V} C O}$ plot $\left(\dot{\mathrm{V}}_{\mathrm{E}}\right.$ on the $\mathrm{y}$-axis and $\dot{\mathrm{V}} \mathrm{CO}_{2}$ on the $\mathrm{x}$-axis). A linear regression line was determined based on exercise data points, excluding data above the respiratory compensation point $(7,22)$. The $\dot{\mathrm{V}}_{\mathrm{E}} / \dot{\mathrm{VCO}}_{2}$ intercept was calculated by extrapolating the regression line to $\dot{\mathrm{V}} \mathrm{CO}_{2}=0$. Maximal voluntary ventilation $(M V V)$ was calculated as $\mathrm{FEV}_{1} \times 40$. Peak $\mathrm{V}_{\mathrm{T}} / \mathrm{FEV}_{1}$ was considered as emphysema factor (19) and peak $\mathrm{V}_{\mathrm{T}} / \mathrm{TLC}$ as dLH parameter during exercise (23) while IC/TLC, RV \% predicted and RV/TLC were used as sLH (24).

\section{Statistical analysis}

The sample size required was based on compare $\mathrm{k}$ means: one-way analysis of variance (ANOVA) pairwise, two-sided equality for $\alpha$ of 0.05 , a power (1- $\beta$ ) of 0.8 to detect this difference by using Medcalc Statistical Software version 19.1.3 (Medcalc Software BV, Ostend, Belgium; https: // www.medcalc.org; 2019). Values were reported as mean \pm SD unless otherwise stated. $\mathrm{P}$ value $<0.05$ was considered significant in all analyses. Intraclass correlation coefficients were used to determine the level of between-investigator agreement in the calculation of the slope and intercept. Between-group comparisons were performed using one-way ANOVA with LSD post-hoc testing of significant variables. Pearson's correlation coefficient $(r)$ was used to assess the correlations between the ventilatory inefficiency parameters $\left(\dot{\mathrm{V}}_{\mathrm{E}} / \dot{\mathrm{V} C O} \mathrm{O}_{2}\right.$ intercept, slope and nadir) and peak $\dot{\mathrm{V}}_{\mathrm{E}} / \mathrm{MVV}$, 
Table 1 Demographics and selected resting pulmonary function variables in control and COPD patients

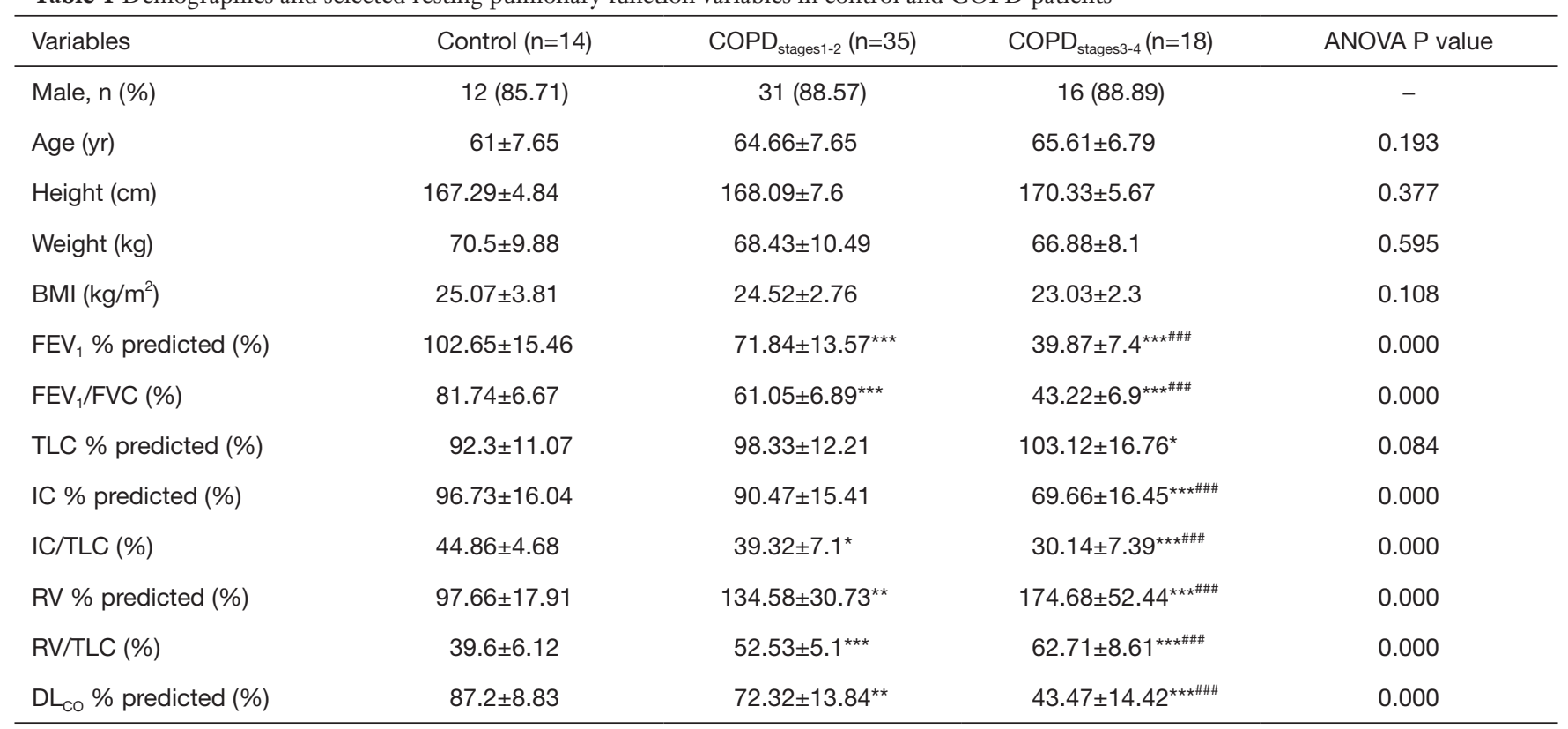

Data are presented as mean \pm standard deviation. The * and " labeled for results of the post-hoc test. *, $\mathrm{P}<0.05$ vs. control; ${ }^{* \star}, \mathrm{P}<0.01$ vs.

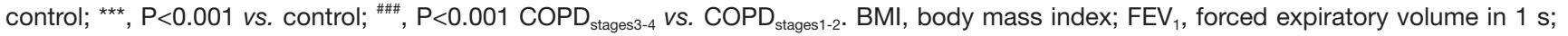
FVC, forced vital capacity; IC, inspiratory capacity; TLC, total lung capacity; RV, residual volume; $\mathrm{DL}_{\mathrm{co}}$, diffusing capacity of the lung for carbon monoxide.

peak $\dot{\mathrm{VO}}_{2}$ /Watt, static and dynamic hyperinflation measures (RV \% predicted, RV/TLC, IC/TLC and peak $\mathrm{V}_{\mathrm{T}} / \mathrm{TLC}$, peak $\left.\mathrm{V}_{\mathrm{T}} / \mathrm{FEV}_{1}\right)$, and airflow limitation $\left(\mathrm{FEV}_{1} \%\right.$ predicted and $\mathrm{FEV}_{1} / \mathrm{FVC}$ ). All analyses were performed with SPSS Statistics 20.0 (IBM, Chicago, USA).

\section{Results}

\section{Participant characteristics and resting spirometric measurements}

As shown in Table 1 , the $\mathrm{COPD}_{\text {stages1-2 }}(\mathrm{n}=35), \mathrm{COPD}_{\text {stages } 3-4}$ $(n=18)$ and control $(n=14)$ were well matched in terms of age, weight, and BMI. There are the expected decreases in $\mathrm{FEV}_{1}$ $\%$ predicted, $\mathrm{FEV}_{1} / \mathrm{FVC}$, IC $\%$ predicted, IC/TLC, $\mathrm{DL}_{\mathrm{CO}} \%$ predicted and the expected increases in RV \% predicted, RV/ TLC, from $\mathrm{COPD}_{\text {stages }-2}$ to $\mathrm{COPD}_{\text {stages } 3-4}(\mathrm{P}<0.001)$. Table 1 shows demographics and selected resting pulmonary function variables in control and COPD patients.

\section{Exercise characteristics}

Table 2 shows the exercise variables at peak exercise in control and COPD patients. All subjects completed the exercise testing without complications. No one repeated the CPET and no one peak workload more than $200 \mathrm{~W}$. Among them ranges of exercise duration were found from 6 to $10 \mathrm{~min}$. Peak exercise capacity was progressively reduced from the control to $\mathrm{COPD}_{\text {stages } 1-2}$ and $\mathrm{COPD}_{\text {stages } 3-4}$ patients. Measures at peak exercise showed that the $\mathrm{COPD}_{\text {stages3-4 }}$ patients had significantly reduced $\dot{\mathrm{V}}_{\mathrm{E}}, \dot{\mathrm{V}} \mathrm{O}_{2}$, $\dot{\mathrm{V}} \mathrm{O}_{2} \%$ predicted, $\dot{\mathrm{V}} \mathrm{O}_{2} / \mathrm{HR}, \dot{\mathrm{V} C O}{ }_{2}$ and $W R$ except peak $\dot{\mathrm{V}}_{\mathrm{E}} / \mathrm{MVV}$ in comparison to control $(\mathrm{P}<0.001)$. $\mathrm{COPD}_{\text {stages } 3-4}$ patients had significantly reduced $\dot{\mathrm{V}}_{2} \%$ predicted, $\dot{\mathrm{V}}_{\mathrm{E}}$, and WR while peak $\dot{\mathrm{V}}_{\mathrm{E}} / \mathrm{MVV}$ increased in comparison to $\mathrm{COPD}_{\text {stages } 1-2}(\mathrm{P}<0.001)$. During exercise, the peak $\mathrm{V}_{\mathrm{T}}$ in $\mathrm{COPD}_{\text {stages } 3-4}(1.3 \pm 0.2)$ was lower than in $\mathrm{COPD}_{\text {stages 1-2 }}$ $(1.64 \pm 0.35)$, and significantly lower than control $(1.79 \pm 0.22)$ $(\mathrm{P}<0.001)$. Considering emphysema factor, peak $\mathrm{V}_{\mathrm{T}} /$ $\mathrm{FEV}_{1}(\%)$ in $\mathrm{COPD}_{\text {stages }-4}(114 \pm 23.28)$ was higher than in $\mathrm{COPD}_{\text {stages1-2 }}(84.72 \pm 17.18)$, and significantly higher than control $(65.49 \pm 12.95)(\mathrm{P}<0.001)$. There was also significant difference between $\mathrm{COPD}_{\text {stages1-2 }}$ and $\mathrm{COPD}_{\text {stages } 3-4}(\mathrm{P}<0.001)$. Regarding the measures of dLH peak $\mathrm{V}_{\mathrm{T}} / \mathrm{TLC}(\%)$, compared to control $(33.15 \pm 5.5)$, COPD stagesl-2 $_{2}(27.45 \pm 5.02$, $\mathrm{P}<0.01)$ and $\mathrm{COPD}_{\text {stages } 3-4}(19.88 \pm 4.78, \mathrm{P}<0.001)$ patients all exhibited significant difference; there was also significant 
Table 2 Selected variables at peak exercise in control and COPD patients

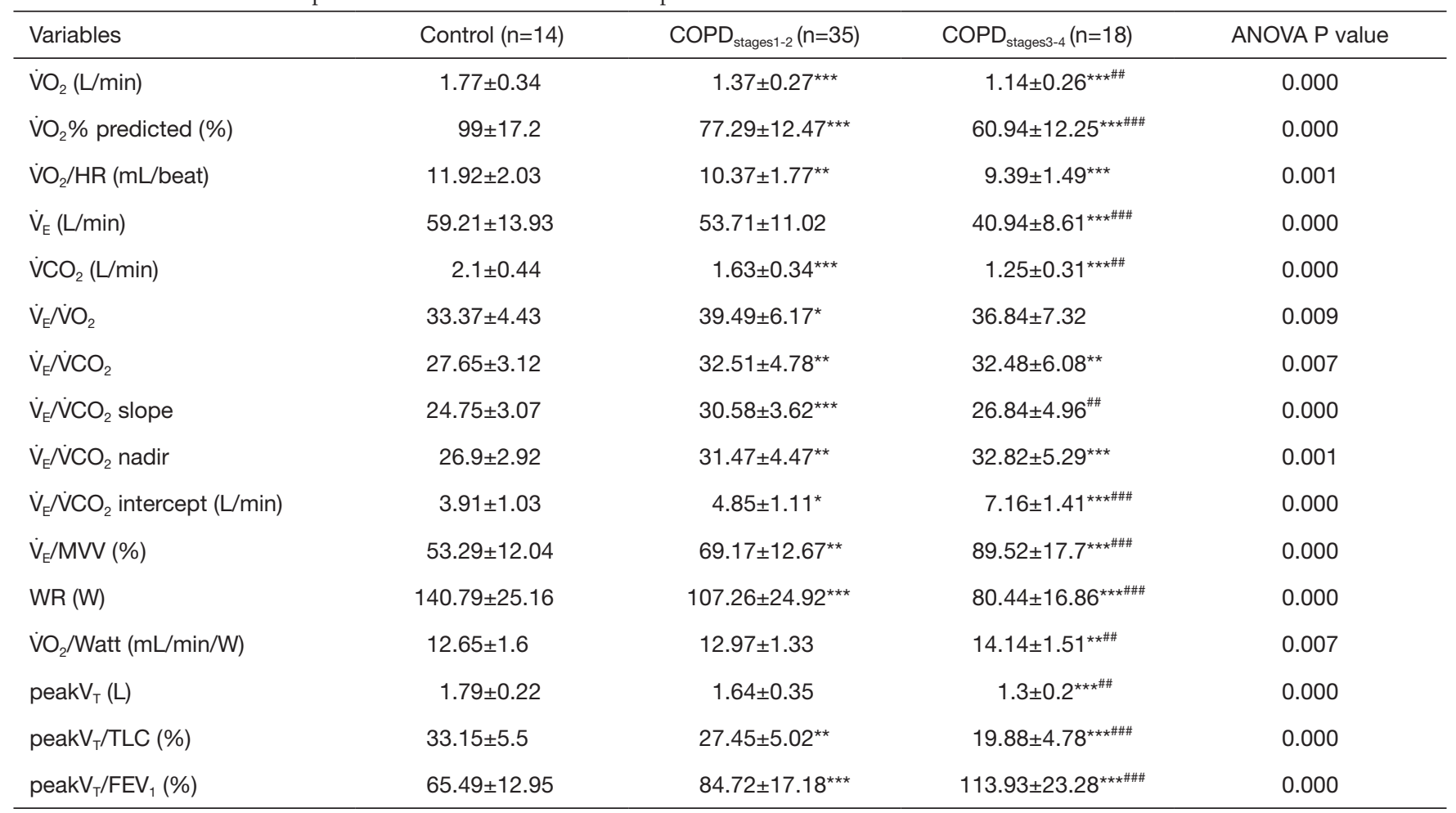

Data are presented as mean \pm standard deviation. The * and ${ }^{*}$ labeled for results of the post-hoc test. ${ }^{*}, \mathrm{P}<0.05$ vs. control; ${ }^{* *}, \mathrm{P}<0.01$ vs.

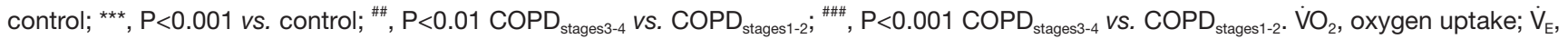
minute ventilation; $\dot{\mathrm{CCO}}_{2}$, carbon dioxide output; $\mathrm{HR}$, heart rate; $\mathrm{MVV}$, maximal voluntary ventilation; WR, work rate; $\mathrm{V}_{\mathrm{T}}$, tidal volume; TLC, total lung capacity; $\mathrm{FEV}_{1}$, forced expiratory volume in $1 \mathrm{~s}$.

difference between $\mathrm{COPD}_{\text {stages1-2 }}$ and $\mathrm{COPD}_{\text {stages } 3-4}(\mathrm{P}<0.001)$.

\section{Ventilatory inefficiency in COPD patients}

The $\dot{\mathrm{V}}_{\mathrm{E}} / \dot{\mathrm{V}} \mathrm{CO}_{2}$ relationships were expressed in terms of the slope, nadir, and intercept. Compared to control $(24.75 \pm 3.07)$, the slope was increased in $\mathrm{COPD}_{\text {stages } 1-2}$ $(30.58 \pm 3.62)$ and decreased in $\mathrm{COPD}_{\text {stages } 3-4}(26.84 \pm 4.96)$. The nadir was increased in $\mathrm{COPD}_{\text {stages } 1-2}(31.47 \pm 4.47$, $\mathrm{P}<0.01)$ and almost stable in $\mathrm{COPD}_{\text {stages } 3-4}(32.82 \pm 5.29$, $\mathrm{P}<0.001)$ in comparison to control $(26.9 \pm 2.92)$. There was no difference between $\mathrm{COPD}_{\text {stages1-2 }}$ and $\mathrm{COPD}_{\text {stages } 3-4}$. As for the intercept, the $\mathrm{COPD}_{\text {stages } 1-2}$ and $\mathrm{COPD}_{\text {stages } 3-4}$ had higher intercepts $(4.85 \pm 1.11, \mathrm{P}<0.05)$, and $(7.16 \pm 1.41$, $\mathrm{P}<0.001)$ respectively in comparison to control $(3.91 \pm 1.03)$. There was significant difference between $\mathrm{COPD}_{\text {stages } 3-4}$ and $\mathrm{COPD}_{\text {stages } 1-2}(\mathrm{P}<0.001) . \dot{\mathrm{V}}_{\mathrm{E}} / \dot{\mathrm{V} C O}_{2}$ intercept increased across the severity spectrum of COPD. Among ventilatory inefficiency parameters (slope, nadir and intercept), only
$\dot{\mathrm{V}}_{\mathrm{E}} / \dot{\mathrm{V} C O} \mathrm{CO}_{2}$ intercept exhibited correlation with peak $\dot{\mathrm{V}} \mathrm{O}_{2} /$ Watt $(\mathrm{r}=0.354, \mathrm{P}=0.003)$ and peak $\dot{\mathrm{V}}_{\mathrm{E}} / \mathrm{MVV}(\mathrm{r}=0.489$, $\mathrm{P}<0.001)$. Figure 1 shows measures of ventilatory inefficiency in control and COPD patients. Figure 2 shows $\dot{\mathrm{V}}_{\mathrm{E}} / \dot{\mathrm{V} C O} \mathrm{CO}_{2}$ intercept in correlation with peak $\dot{\mathrm{V}}_{\mathrm{E}} / \mathrm{MVV}$ and peak $\dot{\mathrm{VO}}_{2} /$ Watt in the entire study group.

\section{Correlation of ventilatory inefficiency with LH and airflow limitation}

Table 3 shows the correlation coefficients of the ventilatory inefficiency parameters and measures of LH, airflow limitation. The relationships between the measures of ventilatory inefficiency and $\mathrm{LH}$ and airflow limitation were assessed in COPD patients. The $\dot{\mathrm{V}}_{\mathrm{E}} / \dot{\mathrm{V}} \mathrm{CO}_{2}$ intercept was correlated with the measures of sLH and $\mathrm{dLH}$ (Table 3), rest IC/TLC $(\mathrm{r}=-0.574, \mathrm{P}<0.001), \mathrm{RV} \%$ predicted $(\mathrm{r}=0.571$, $\mathrm{P}<0.001)$, RV/TLC $(\mathrm{r}=0.588, \mathrm{P}<0.001)$, peak $\mathrm{V}_{\mathrm{T}} / \mathrm{FEV}_{1}$ $(\mathrm{r}=0.482, \mathrm{P}<0.001)$ and peak $\mathrm{V}_{\mathrm{T}} / \mathrm{TLC}(\mathrm{r}=-0.585, \mathrm{P}<0.001)$ 

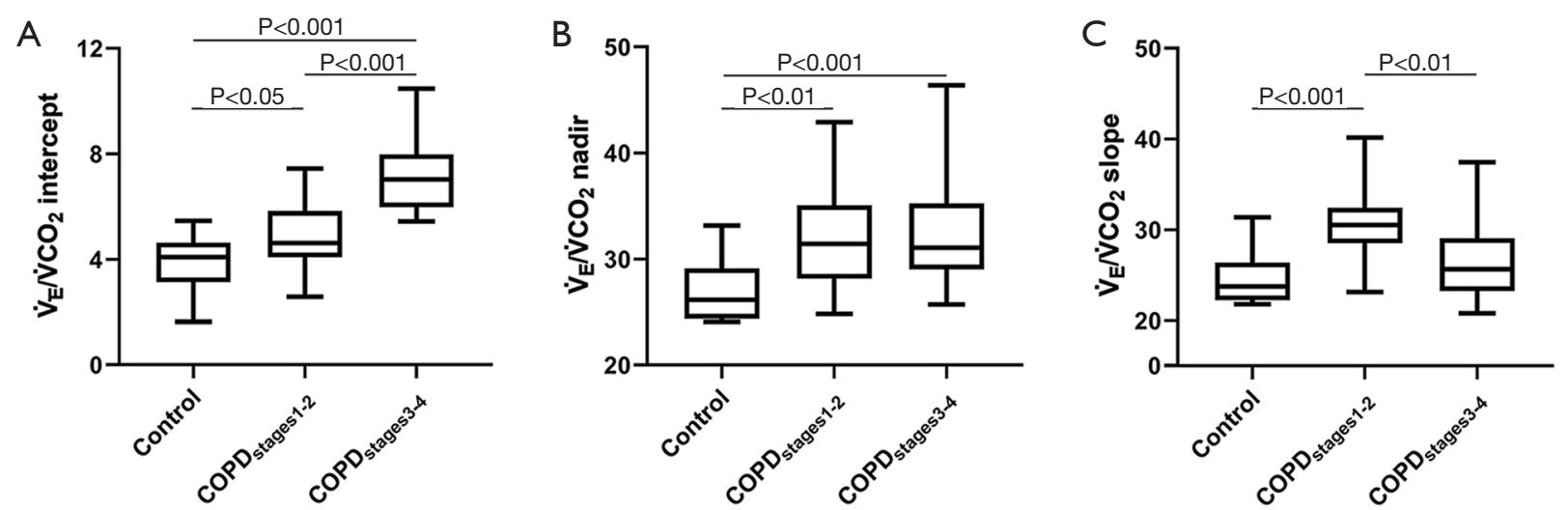

Figure 1 Measures of ventilatory inefficiency in control and COPD patients. (A) $\dot{\mathrm{V}}_{\mathrm{E}} / \dot{\mathrm{VCO}}_{2}$ intercept, (B) $\dot{\mathrm{V}}_{\mathrm{E}} / \dot{\mathrm{VCO}}_{2}$ nadir, and $(\mathrm{C}) \dot{\mathrm{V}}_{\mathrm{E}} /$ $\dot{\mathrm{VCO}}_{2}$ slope in control and COPD patients. (A) The $\mathrm{COPD}_{\text {stages1-2 }}$ and $\mathrm{COPD}_{\text {stages } 3-4}$ had higher intercepts in comparison to control. $\dot{\mathrm{V}}_{\mathrm{E}} / \dot{\mathrm{V}}$ $\mathrm{CO}_{2}$ intercept increased across the severity spectrum of COPD $(\mathrm{P}<0.001)$. (B) The nadir was increased in COPD patients in comparison to control. There was no difference between $\mathrm{COPD}_{\text {stages1-2 }}$ and $\mathrm{COPD}_{\text {stages } 3-4 \cdot}(\mathrm{C}) \mathrm{Compared}$ to control, the slope was increased in $\mathrm{COPD}_{\text {stages } 1-2}$

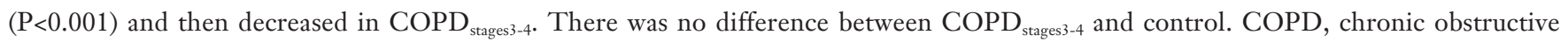
pulmonary disease; $\dot{\mathrm{V}}_{\mathrm{E}}$, minute ventilation; $\dot{\mathrm{VCO}}_{2}$, carbon dioxide output.

A

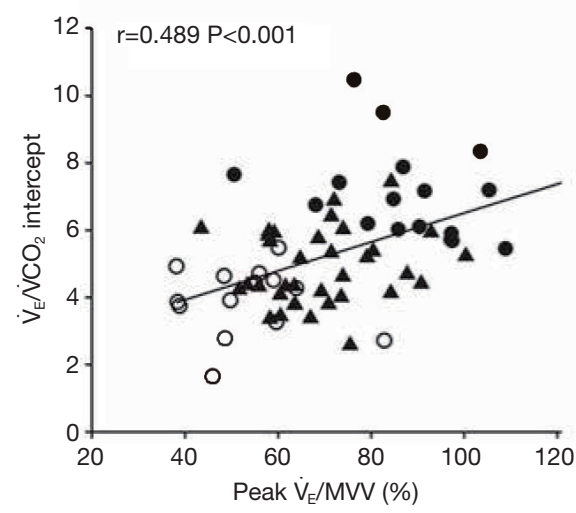

B

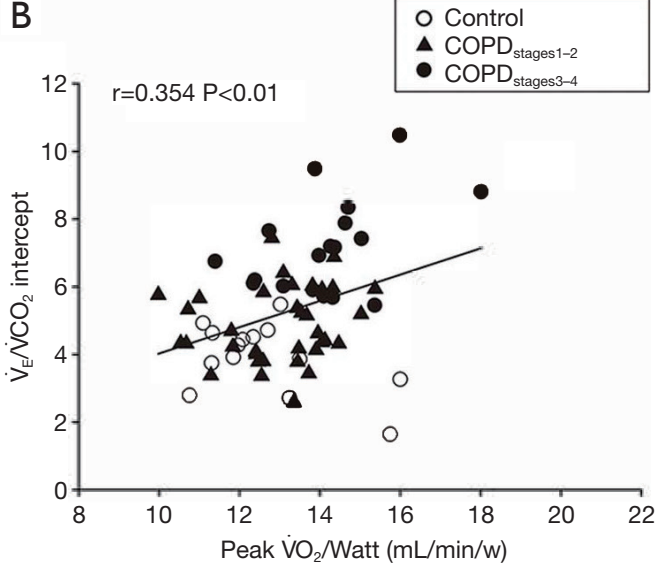

Figure 2 Correlations between $\dot{\mathrm{V}}_{\mathrm{E}} / \dot{\mathrm{V} C O} \mathrm{O}_{2}$ intercept and peak $\dot{\mathrm{V}}_{\mathrm{E}} / \mathrm{MVV}$ and peak $\dot{\mathrm{VO}}_{2} / \mathrm{Watt}$ in the entire study group. (A) $\dot{\mathrm{V}}_{\mathrm{E}} / \dot{\mathrm{VCO}}{ }_{2}$ intercept vs. peak $\dot{\mathrm{V}}_{\mathrm{E}} / \mathrm{MVV}(\mathrm{r}=0.489, \mathrm{P}<0.001)$; (B) $\dot{\mathrm{V}}_{\mathrm{E}} / \dot{\mathrm{VCO}}_{2}$ intercept $v$ s. peak $\dot{\mathrm{VO}}_{2} / \mathrm{Watt}(\mathrm{r}=0.354, \mathrm{P}<0.01)$. MVV, maximal voluntary ventilation; $\dot{\mathrm{V}}_{\mathrm{E}}$, minute ventilation; $\dot{\mathrm{V}} \mathrm{CO}_{2}$, carbon dioxide output; $\dot{\mathrm{VO}}_{2}$, oxygen uptake.

respectively while the $\dot{\mathrm{V}}_{\mathrm{E}} / \dot{\mathrm{V} C O}_{2}$ slope not. The $\dot{\mathrm{V}}_{\mathrm{E}} / \dot{\mathrm{V} C O}$ nadir was also correlated with rest IC/TLC ( $\mathrm{r}=-0.35$, $\mathrm{P}=0.004), \mathrm{RV} \%$ predicted $(\mathrm{r}=0.383, \mathrm{P}=0.001) \mathrm{RV} / \mathrm{TLC}$ $(\mathrm{r}=0.431, \mathrm{P}<0.001)$, and peak $\mathrm{V}_{\mathrm{T}} / \mathrm{TLC}(\mathrm{r}=-0.503, \mathrm{P}<0.001)$. A similar pattern of results was found in correlation to airflow limitation. The $\dot{\mathrm{V}}_{\mathrm{E}} / \dot{\mathrm{V}} \mathrm{CO}_{2}$ intercept showed correlation with $\mathrm{FEV}_{1} \%$ predicted $(\mathrm{r}=-0.606, \mathrm{P}<0.001)$ and $\mathrm{FEV}_{1} / \mathrm{FVC}(\mathrm{r}=-0.629, \mathrm{P}<0.001)$ while $\dot{\mathrm{V}}_{\mathrm{E}} / \dot{\mathrm{V} C O}_{2}$ slope not. $\dot{\mathrm{V}}_{\mathrm{E}} / \dot{\mathrm{V} C O}{ }_{2}$ nadir was also correlated with $\mathrm{FEV}_{1} \%$ predicted $(\mathrm{r}=-0.368, \mathrm{P}=0.002)$ and $\mathrm{FEV}_{1} / \mathrm{FVC}(\mathrm{r}=0.424, \mathrm{P}<0.001)$.

\section{Discussion}

The main finding of this study was that the $\dot{\mathrm{V}}_{\mathrm{E}} / \dot{\mathrm{V}} \mathrm{CO}_{2}$ intercept was consistently correlated with worsening static and dynamic LH and increasing airflow limitation in COPD. This suggests that it could be a useful index for ventilatory inefficiency during incremental exercise in COPD.

Abnormalities in the $\dot{\mathrm{V}}_{\mathrm{E}} / \dot{\mathrm{V} C O}$ relationship were present across the spectrum of COPD severity. Increases in both the $\dot{\mathrm{V}}_{\mathrm{E}} / \dot{\mathrm{V}} \mathrm{CO}_{2}$ nadir and slope were associated with lower 
Table 3 Correlation coefficients for ventilatory inefficiency parameters with measures of LH and airflow limitation

\begin{tabular}{|c|c|c|c|c|c|c|}
\hline Variables & \multicolumn{2}{|c|}{$\dot{\mathrm{V}}_{\mathrm{E}} / \dot{\mathrm{V} C \mathrm{O}_{2}}$ slope } & \multicolumn{2}{|c|}{$\dot{\mathrm{V}}_{\mathrm{E}} \dot{\mathrm{NCO}}_{2}$ nadir } & \multicolumn{2}{|c|}{$\dot{\mathrm{V}}_{\mathrm{E}} / \mathrm{VCO}_{2}$ intercept } \\
\hline Peak $V_{T} / T L C(\%)$ & -0.148 & 0.232 & -0.503 & 0.000 & -0.585 & 0.000 \\
\hline Peak $\mathrm{V}_{\mathrm{T}} / \mathrm{FEV}_{1}$ & -0.253 & 0.036 & 0.195 & 0.113 & 0.482 & 0.000 \\
\hline IC/TLC (\%) & -0.006 & 0.962 & -0.35 & 0.004 & -0.574 & 0.000 \\
\hline RV/TLC (\%) & 0.191 & 0.121 & 0.431 & 0.000 & 0.588 & 0.000 \\
\hline $\mathrm{FEV}_{1} / \mathrm{FVC}(\%)$ & -0.167 & 0.178 & -0.434 & 0.000 & -0.629 & 0.000 \\
\hline $\mathrm{FEV}_{1} \%$ predicted $(\%)$ & -0.064 & 0.609 & -0.368 & 0.002 & -0.606 & 0.000 \\
\hline$\dot{\mathrm{V}}_{\mathrm{E}} / \mathrm{MVV}(\%)$ & 0.181 & 0.142 & 0.424 & 0.000 & 0.489 & 0.000 \\
\hline
\end{tabular}

$\mathrm{V}_{\mathrm{T}}$, tidal volume; IC, inspiratory capacity; TLC, total lung capacity; RV, residual volume, $\mathrm{FEV}_{1}$, forced expiratory volume in $1 \mathrm{~s}$; FVC, forced vital capacity; $\dot{\mathrm{V}}_{\mathrm{E}}$, minute ventilation; $\mathrm{MVV}$, maximal voluntary ventilation; $\dot{\mathrm{VO}}_{2}$, oxygen uptake.

maximal exercise capacity in COPD patients (10,25-27). In our study, compared to control, COPD stages $1-2_{2}$ had a higher slope and nadir. For healthy subjects who can tolerate high levels of exercise, the $\dot{\mathrm{V}}_{\mathrm{E}} / \mathrm{VCO}_{2}$ nadir and ratio at the anaerobic threshold were usually very similar (7). As the lactate threshold may not always be identified, particularly in clinical populations with low exercise capacity (28), the $\dot{\mathrm{V}}_{\mathrm{E}} / \dot{\mathrm{V}} \mathrm{CO}_{2}$ nadir seems a more accurate indication of ventilatory efficiency than the $\dot{\mathrm{V}}_{\mathrm{E}} / \dot{\mathrm{V}}_{\mathrm{CO}}$ at the lactate threshold. However, the $\dot{\mathrm{V}}_{\mathrm{E}} / \dot{\mathrm{V}} \mathrm{CO}_{2}$ nadir, might underestimate ventilatory efficiency for early lactic acidosis or an excessively short test duration (9). The results showed patients with $\mathrm{COPD}_{\text {stages1-2 }}$ had a higher slope and nadir, while $\mathrm{COPD}_{\text {stages } 3-4}$ had a lower slope, and a stable nadir. The $\dot{\mathrm{V}}_{\mathrm{E}} / \dot{\mathrm{VCO}}_{2}$ intercept, by definition, cannot be constrained by worsening mechanics (as the slope) or test duration (as the nadir). It should be recognized that including the data points after the RCP will necessarily increase the computed slope and decrease the computed intercept. Furthermore, including the data points after the RCP does not accurately reflect $\dot{\mathrm{V}}_{\mathrm{E}} v s$. $\dot{\mathrm{VCO}}_{2}$ plot profile. In present study, we excluded the data above the RCP for linear regression to calculate the slope and intercept. The $\dot{\mathrm{V}}_{\mathrm{E}} / \dot{\mathrm{V}} \mathrm{CO}_{2}$ intercept was higher across all stages in current study. This is in line with a retrospective study reported by Neder of 316 patients with a large range of resting pulmonary function ( $\mathrm{FEV}_{1}=12-148 \%$ predicted) (10). A lower slope, stable nadir, and a higher intercept in more advanced COPD stage likely reflected the opposite changes in $\dot{\mathrm{V}}_{\mathrm{E}} / \dot{\mathrm{V} C O} \mathrm{O}_{2}$ slope and intercept.

There is mounting evidence that ventilatory inefficiency parameters are powerful prognostic predictors in COPD patients with comorbidity. A retrospective study of 145 COPD patients undergoing surgery for non-small cell cancer (NSCLC) showed that a $\dot{\mathrm{V}}_{\mathrm{E}} / \dot{\mathrm{VCO}}_{2}$ slope $>34$ predicted mortality after lung resection surgery (29). A highintensity pulmonary rehabilitation programs could improve ventilatory efficiency in patients with COPD undergoing lung resection for NSCLC $\left(\dot{\mathrm{V}}_{\mathrm{E}} / \dot{\mathrm{V} C O}{ }_{2}\right.$ slope from $32.0 \pm 2.8$ to $30.1 \pm 4.0, \mathrm{P}<0.01)(30)$. As for the $\dot{\mathrm{V}}_{\mathrm{E}} / \dot{\mathrm{V}} \mathrm{CO}_{2}$ nadir, Neder $e t a l$. reported that a value $>34$ in combination with resting hyperinflation predicted mortality in COPD (31). Importantly, a series of studies demonstrated that the $\dot{\mathrm{V}}_{\mathrm{E}}$ / $\dot{\mathrm{V}} \mathrm{CO}_{2}$ intercept (cutoff values ranging from $2.64-4.07 \mathrm{~L} / \mathrm{min}$ ) might discriminate COPD from heart failure $(32,33)$.

Ventilatory inefficiency increases ventilatory demand and exercise capacity limitation in COPD patients. The increase of peak $\dot{\mathrm{V}}_{\mathrm{E}} / \mathrm{MVV}$ across all stages reflected the worsening breathing reserve in COPD. Interestingly, the $\dot{\mathrm{V}}_{\mathrm{E}} / \dot{\mathrm{V}} \mathrm{CO}_{2}$ nadir and intercept were highly positively related to the peak $\dot{\mathrm{V}}_{\mathrm{E}} / \mathrm{MVV}$ in the current study. $\dot{\mathrm{V}} \mathrm{O}_{2}-$ work rate relationship describes how much $\mathrm{O}_{2}$ is utilized by exercise subject in relation to the quantity of external work performed. Among the $\dot{\mathrm{V}}_{\mathrm{E}} / \dot{\mathrm{V} C O}$ slope, nadir and intercept, only $\dot{\mathrm{V}}_{\mathrm{E}} / \dot{\mathrm{VCO}}_{2}$ intercept was positively related to the peak $\dot{\mathrm{V}} \mathrm{O}_{2} /$ Watt (Table 3). This was consistent with Neder's reports that $\dot{\mathrm{V}}_{\mathrm{E}} / \dot{\mathrm{V} C O}{ }_{2}$ intercept was correlated with the peak metabolic stress $\left(\dot{\mathrm{VO}}_{2}\right.$ peak) (10). 
Two other independent studies found correlations between the $\dot{\mathrm{V}}_{\mathrm{E}} / \dot{\mathrm{VCO}}_{2}$ nadir and emphysema severity on high-resolution computed tomography scans in COPD patients with largely preserved $\mathrm{FEV}_{1}(34,35)$. Teopompi reported that patients with the ratio of peak $\mathrm{V}_{\mathrm{T}} / \mathrm{FEV}_{1} \geq 1$ had a predominant pulmonary emphysema profile, thereby showing a higher degree of airflow obstruction (19). We found the $\dot{\mathrm{V}}_{\mathrm{E}} / \dot{\mathrm{V} C \mathrm{CO}_{2}}$ intercept was positively related to peak $\mathrm{V}_{\mathrm{T}} / \mathrm{FEV}_{1}$ and particularly the ratio of peak $\mathrm{V}_{\mathrm{T}} / \mathrm{FEV}_{1}$ in $\mathrm{COPD}_{\text {stages } 3-4}$ was more than $1(1.13 \pm 0.23)$. The consequence of pulmonary parenchyma destruction and loss of elastic recoil is static hyperinflation. Emphysema and development of expiratory flow limitation promote progressive air trapping with an increase in the EELV and a decrease in IC. RV was also increased in emphysema/COPD due to both loss of elastic recoil and premature closure of the small airways $(3,36,37)$. In expiratory flow-limited patients, EELV was a continuous dynamic variable dependent on expiratory duration and breathing pattern. DH refers to this temporary and variable increase in EELV. As ventilation increases and expiratory duration decreases, there is not enough time to allow EELV to decline to its baseline resting value (38).

Studies reported that both sLH and the degree of dLH were associated with the development of dyspnea and exercise intolerance in COPD patients $(39,40)$. Assuming TLC stability, the resting IC and inspiratory reserve (IRV) showed the operating position of $\mathrm{V}_{\mathrm{T}}$ relative to the TLC. The smaller the resting IC, the shorter the exercise time before $V_{\mathrm{T}}$ plateaus and dyspnea abruptly escalates (41). A 4-year longitudinal study reported that significant reductions in peak $\dot{\mathrm{VO}}_{2}$ and $\dot{\mathrm{V}}_{\mathrm{E}}$ were related to a decreased resting IC (42). Both rest IC/TLC and RV/TLC in patients with COPD reflected the degree of sLH and also the functional reserve. Rest IC/TLC was also found to be a valuable and independent predictor of all-cause and respiratory mortality in COPD compared with that of the BODE (body mass index, airflow obstruction, dyspnea, exercise performance) index (43). The present study showed that the $\dot{\mathrm{V}}_{\mathrm{E}} / \dot{\mathrm{V}} \mathrm{CO}_{2}$ intercept was more strongly correlated with a series of highly relevant parameters, rest IC/TLC $(\mathrm{r}=-0.574, \mathrm{P}<0.001), \mathrm{RV} \%$ predicted $(\mathrm{r}=0.571, \mathrm{P}<0.001)$ and RV/TLC $(\mathrm{r}=0.588, \mathrm{P}<0.001)$, and $\dot{\mathrm{V}}_{\mathrm{E}} / \dot{\mathrm{VCO}}_{2}$ nadir with rest IC/TLC $(r=-0.35, P=0.004), R V \%$ predicted $(r=0.383$, $\mathrm{P}=0.001)$, RV/TLC $(\mathrm{r}=0.431, \mathrm{P}<0.001)$. The $\dot{\mathrm{V}}_{\mathrm{E}} / \dot{\mathrm{VCO}}_{2}$ slope had no correlation with sLH parameters.

A progressive increase in EELV, while IC decreases was associated with dyspnea and exercise intolerance in COPD during exercise (44). Serial measurements of IC to detect its changes were reported as a classic way to identify dynamic hyperinflation $(39,40,45)$. However, the study participants had to be familiar with the maneuvers, and IC measurements also had to be standardized by researchers (46). Dynamic IC measurement is not recommended for ramp-pattern protocols where $V_{T}$ cannot steadily proceed to perform the IC maneuver. However, the ramp-pattern protocol is a widely used for incremental testing (46). Elevated EELV can substantially constrain $V_{T}$ expansion at higher exercise intensities. It is logical that COPD patients reach a $V_{T}$ plateau and have similar minimal inspiratory reserve volume. Chuang et al. investigated peak $\mathrm{V}_{\mathrm{T}} / \mathrm{TLC}$ as a convenient new marker of DH and reported a cutoff of 0.27 (23). In this study, we used peak $\mathrm{V}_{\mathrm{T}}$ /TLC instead of $\Delta$ (peak-rest) IC as the index of dLH. Among ventilatory inefficiency parameters (slope, nadir, and intercept), we found that only the $\dot{\mathrm{V}}_{\mathrm{E}} / \dot{\mathrm{VCO}}_{2}$ intercept exhibited a better correlation to peak $\mathrm{V}_{\mathrm{T}} / \mathrm{TLC}(\mathrm{r}=-0.585, \mathrm{P}<0.001)$. To our knowledge, this is the first study to describe the relationship between ventilatory inefficiency parameters and rest IC/ TLC, RV/TLC and peak $\mathrm{V}_{\mathrm{T}} / \mathrm{TLC}$ as static and dynamic $\mathrm{LH}$ index. Interestingly, the $\dot{\mathrm{V}}_{\mathrm{E}} / \mathrm{VCCO}_{2}$ intercept was also correlated with worsening pulmonary airflow limitation as indicated by $\mathrm{FEV}_{1} / \mathrm{FVC}(\mathrm{r}=-0.629, \mathrm{P}<0.001)$ and $\mathrm{FEV}_{1}$ $\%$ predicted $(\mathrm{r}=-0.606, \mathrm{P}<0.001)$. This was consistent with Teopompi's reports, expressed as $\mathrm{FEV}_{1} \%$ predicted $(\mathrm{r}=-0.482, \mathrm{P}<0.001)(19)$ and $\mathrm{FEV}_{1} / \mathrm{VC}$ in subjects with COPD ( $r=-0.38, \mathrm{P}=0.009)$ (47).

A limitation of our study is the small number of subjects although well matched proportions of female patients in three groups (2/14 in control, $4 / 35$ in COPD $_{\text {stages1-2, }}$, and $2 / 18$ in $\mathrm{COPD}_{\text {stages3-4, }}$, respectively). We did not correlated the $\dot{\mathrm{V}}_{\mathrm{E}} / \dot{\mathrm{V} C \mathrm{CO}_{2}}$ slope, nadir and intercept with dyspnea in current study. Notably, our findings of a significantly lower $\dot{\mathrm{V}}_{\mathrm{E}} / \dot{\mathrm{V} C O}_{2}$ slope in $\mathrm{COPD}_{\text {stages } 3-4}$ compared with $\mathrm{COPD}_{\text {stages1-2 }}$ might be due to changes in $\mathrm{V}_{\mathrm{D}} / \mathrm{V}_{\mathrm{T}}$, which we did not calculation in present study. We believe that the increased ventilatory inefficiency associated with $\mathrm{LH}$ might be more pronounced in patients with more advanced COPD. However, in the absence of a true criterion test for ventilatory inefficiency during exercise, we relied on a set of variables that are indirect markers of pulmonary gasexchange disturbances. We also recognize that variables related to disease phenotypes and test factors (e.g., duration) affect different strategies to reflect ventilatory inefficiency. Therefore, we can only infer, not establish the mechanism underlying the ventilatory inefficiency in COPD patients during exercise. Further an additional study with $\mathrm{V}_{\mathrm{D}} / \mathrm{V}_{\mathrm{T}}$ and 
$\mathrm{PaCO}_{2}$ measurements is needed.

\section{Conclusions}

$\dot{\mathrm{V}}_{\mathrm{E}} / \dot{\mathrm{V}} \mathrm{CO}_{2}$ intercept increased across the severity spectrum of COPD patients and consistently correlated with exercise capacity. Increases in $\dot{\mathrm{V}}_{\mathrm{E}} / \dot{\mathrm{V}} \mathrm{CO}_{2}$ intercept were consistently correlated with worsening static and dynamic LH and airflow limitation. A hitherto underappreciated variable, the $\dot{\mathrm{V}}_{\mathrm{E}} / \dot{\mathrm{V}} \mathrm{CO}_{2}$ intercept, was found to be a particularly useful index of ventilatory inefficiency during incremental exercise in COPD patients. Further comprehensive studies are promised to corroborate these preliminary results.

\section{Acknowledgments}

The authors would like to appreciate Richard Casaburi, $\mathrm{PhD}, \mathrm{MD}$, Janos Porszasz, MD, PhD, from Los Angeles Biomedical Research Institute at Harbor-UCLA Medical Center, explanation of the concept. We also would like to thank Nan Jia, Xujuan Zhao, and Bin Li from the pulmonary function investigation unit of the Department of Respiratory Beijing Friendship Hospital, Capital Medical University for performing the lung function test and the medical support during the execution of the CPET.

Funding: This study was supported by the Capital's Funds for Health Improvement and Research (No. 2018-2-2024, Beijing, China).

\section{Footnote}

Reporting Checklist: The authors have completed the STROBE reporting checklist. Available at http://dx.doi. org/10.21037/jtd-20-2725

Data Sharing Statement: Available at http://dx.doi. org/10.21037/jtd-20-2725

Peer Review File: Available at http://dx.doi.org/10.21037/jtd20-2725

Conflicts of Interest: All authors have completed the ICMJE uniform disclosure form (available at http://dx.doi. org/10.21037/jtd-20-2725). The authors have no conflicts of interest to declare.

Ethical Statement: The authors are accountable for all aspects of the work in ensuring that questions related to the accuracy or integrity of any part of the work are appropriately investigated and resolved. The study was conducted in accordance with the Declaration of Helsinki (as revised in 2013). The study was approved by the Institutional ethics committee of Beijing Friendship Hospital of Capital Medical University (No. 2018-P2-04801 ) and the written informed consent was obtained from every participant.

Open Access Statement: This is an Open Access article distributed in accordance with the Creative Commons Attribution-NonCommercial-NoDerivs 4.0 International License (CC BY-NC-ND 4.0), which permits the noncommercial replication and distribution of the article with the strict proviso that no changes or edits are made and the original work is properly cited (including links to both the formal publication through the relevant DOI and the license). See: https://creativecommons.org/licenses/by-nc-nd/4.0/.

\section{References}

1. O'Donnell DE, Laveneziana P, Webb K, et al. Chronic obstructive pulmonary disease: clinical integrative physiology. Clin Chest Med 2014;35:51-69.

2. Gagnon P, Guenette JA, Langer D, et al. Pathogenesis of hyperinflation in chronic obstructive pulmonary disease. Int J Chron Obstruct Pulmon Dis 2014;9:187-201.

3. Rossi A, Aisanov Z, Avdeev S, et al. Mechanisms, assessment and therapeutic implications of lung hyperinflation in COPD. Respir Med 2015;109:785-802.

4. Varga J. Mechanisms to dyspnoea and dynamic hyperinflation related exercise intolerance in COPD. Acta Physiol Hung 2015;102:163-75.

5. Cooper CB. The connection between chronic obstructive pulmonary disease symptoms and hyperinflation and its impact on exercise and function. Am J Med 2006;119:21-31.

6. Palange $\mathrm{P}$, Ward SA, Carlsen KH, et al. Recommendations on the use of exercise testing in clinical practice. Eur Respir J 2007;29:185-209.

7. Sun XG, Hansen JE, Garatachea N, et al. Ventilatory efficiency during exercise in healthy subjects. Am J Respir Crit Care Med 2002;166:1443-8.

8. Barron A, Dhutia N, Mayet J, et al. Test-retest repeatability of cardiopulmonary exercise test variables in patients with cardiac or respiratory disease. Eur J Prev Cardiol 2014;21:445-53.

9. Neder JA, Nery LE, Peres C, et.al. Reference values for dynamic responses to incremental cycle ergometry in 
males and females aged 20 to 80 . Am J Respir Crit Care Med 2001;164:1481-6.

10. Neder JA, Arbex FF, Alencar MC, et al. Exercise ventilatory inefficiency in mild to end-stage COPD. Eur Respir J 2015;45:377-87.

11. Paoletti P, De Filippis F, Fraioli F, et al. Cardiopulmonary exercise testing (CPET) in pulmonary emphysema. Respir Physiol Neurobiol 2011;179:167-73.

12. Chin RC, Guenette JA, Cheng S, et al. Does the respiratory system limit exercise in mild chronic obstructive pulmonary disease? Am J Respir Crit Care Med 2013;187:1315-23.

13. Thirapatarapong W, Armstrong HF, Bartels MN. Comparison of cardiopulmonary exercise testing variables in COPD patients with and without coronary artery disease. Heart Lung 2014;43:146-51.

14. Guazzi M, Myers J, Vicenzi M, et al. Cardiopulmonary exercise testing characteristics in heart failure patients with and without concomitant chronic obstructive pulmonary disease. Am Heart J 2010;160:900-5.

15. Holverda S, Bogaard HJ, Groepenhoff H, et al. Cardiopulmonary exercise test characteristics in patients with chronic obstructive pulmonary disease and associated pulmonary hypertension. Respiration 2008;76:160-7.

16. Vonbank K, Funk GC, Marzluf B, et al. Abnormal pulmonary arterial pressure limits exercise capacity in patients with COPD. Wien Klin Wochenschr 2008;120:749-55.

17. Ward SA, Whipp BJ. Ventilatory control during exercise with increased external dead space. J Appl Physiol Respir Environ Exerc Physiol 1980;48:225-31.

18. Agostoni P, Apostolo A, Sciomer S. Evolution of the concept of ventilatory limitation during exercise. Combining the pneumologist and cardiologist point of view. Respir Physiol Neurobiol 2011;179:127-8.

19. Teopompi E, Tzani P, Aiello M, et al. Excess ventilation and ventilatory constraints during exercise in patients with chronic obstructive pulmonary disease. Respir Physiol Neurobiol 2014;197:9-14.

20. Vogelmeier CF, Criner GJ, Martinez FJ, et al. Global Strategy for the Diagnosis, Management, and Prevention of Chronic Obstructive Lung Disease 2017 Report. GOLD Executive Summary. Am J Respir Crit Care Med 2017;195:557-82.

21. Miller MR, Hankinson J, Brusasco V, et al. Standardisation of spirometry. Eur Respir J 2005;26:319-38.

22. Neder JA, Stein R. A simplified strategy for the estimation of the exercise ventilatory thresholds. Med Sci Sports
Exerc 2006;38:1007-13.

23. Chuang ML, Hsieh MJ, Wu TC, et al. Developing a New Marker of Dynamic Hyperinflation in Patients with Obstructive Airway Disease - an observational study. Sci Rep 2019;9:7514.

24. van Geffen WH, Kerstjens HA. Static and dynamic hyperinflation during severe acute exacerbations of chronic obstructive pulmonary disease. Int J Chron Obstruct Pulmon Dis 2018;13:1269-77.

25. Caviedes IR, Delgado I, Soto R. Ventilatory Inefficiency as a Limiting Factor for Exercise in Patients With COPD. Respiratory Care 2012;57:583-9.

26. Maekura R, Hiraga T, Miki K, et al. Differences in physiological response to exercise in patients with different COPD severity. Respir Care 2014;59:252-62.

27. Chuang ML. Mechanisms affecting exercise ventilatory inefficiency-airflow obstruction relationship in male patients with chronic obstructive pulmonary disease. Respir Res 2020;21:206.

28. Agostoni P, Corra U, Cattadori G, et al. Prognostic value of indeterminable anaerobic threshold in heart failure. Circ Heart Fail 2013;6:977-87.

29. Torchio R, Guglielmo M, Giardino R, et al. Exercise ventilatory inefficiency and mortality in patients with chronic obstructive pulmonary disease undergoing surgery for non-small-cell lung cancer. Eur J Cardiothorac Surg 2010;38:14-9.

30. Perrotta F, Cennamo A, Cerqua FS, et al. Effects of a highintensity pulmonary rehabilitation program on the minute ventilation/carbon dioxide output slope during exercise in a cohort of patients with COPD undergoing lung resection for non-small cell lung cancer. J Bras Pneumol 2019;45:e20180132.

31. Neder JA, Alharbi A, Berton DC, et al. Exercise Ventilatory Inefficiency Adds to Lung Function in Predicting Mortality in COPD. COPD 2016;13:416-24.

32. Smith JR, Van Iterson EH, Johnson BD, et al. Exercise ventilatory inefficiency in heart failure and chronic obstructive pulmonary disease. Int J Cardiol 2019;274:232-6.

33. Apostolo A, Laveneziana P, Palange $P$, et al. Impact of chronic obstructive pulmonary disease on exercise ventilatory efficiency in heart failure. Int J Cardiol 2015;189:134-40.

34. Jones JH, Zelt JT, Hirai DM, et al. Emphysema on Thoracic CT and Exercise Ventilatory Inefficiency in Mild-to-Moderate COPD. COPD 2017;14:210-8.

35. Crisafulli E, Alfieri V, Silva M, et al. Relationships between 
emphysema and airways metrics at High-Resolution

Computed Tomography (HRCT) and ventilatory response to exercise in mild to moderate COPD patients. Respir Med 2016;117:207-14.

36. Gibson GJ. Pulmonary hyperinflation a clinical overview. Eur Respir J. 1996;9:2640-9.

37. Macklem PT. Therapeutic implications of the pathophysiology of COPD. Eur Respir J 2010;35:676-80.

38. Laveneziana P, Guenette JA, Webb KA, et al. New physiological insights into dyspnea and exercise intolerance in chronic obstructive pulmonary disease patients. Expert Rev Respir Med 2012;6:651-62.

39. O'Donnell DE, Revill SM, Webb KA. Dynamic hyperinflation and exercise intolerance in chronic obstructive pulmonary disease. Am J Respir Crit Care Med 2001;164:770-7.

40. O'Donnell DE, Webb KA. Exertional breathlessness in patients with chronic airflow limitation. The role of lung hyperinflation. Am Rev Respir Dis 1993;148:1351-7.

41. O'Donnell DE, Milne KM, James MD, et al. Dyspnea in COPD: New Mechanistic Insights and Management

Cite this article as: Lin F, Nie S, Zhao R, Cao M, Yuan W, Li Y, Tan C, Xu B, Wang H. Intercept of minute ventilation versus carbon dioxide output relationship as an index of ventilatory inefficiency in chronic obstructive pulmonary disease. J Thorac Dis 2021;13(3):1553-1563. doi: 10.21037/jtd-202725
Implications. Adv Ther 2020;37:41-60.

42. Frisk B, Hardie JA, Espehaug B, et al. Peak oxygen uptake and breathing pattern in COPD patients--a four-year longitudinal study. BMC Pulm Med 2015;15:93.

43. Casanova C, Cote C, de Torres JP, et al. Inspiratory-tototal lung capacity ratio predicts mortality in patients with chronic obstructive pulmonary disease. Am J Respir Crit Care Med 2005;171:591-7.

44. O'Donnell DE, Fluge T, Gerken F, et al. Effects of tiotropium on lung hyperinflation, dyspnoea and exercise tolerance in COPD. Eur Respir J 2004;23:832-40.

45. Casaburi R, Rennard SI. Exercise limitation in chronic obstructive pulmonary disease. The O'Donnell threshold. Am J Respir Crit Care Med 2015;191:873-5.

46. Guenette JA, Chin RC, Cory JM, et al. Inspiratory Capacity during Exercise: Measurement, Analysis, and Interpretation. Pulm Med 2013;2013:956081.

47. Teopompi E, Tzani P, Aiello M, et al. Ventilatory response to carbon dioxide output in subjects with congestive heart failure and in patients with COPD with comparable exercise capacity. Respir Care 2014;59:1034-41. 